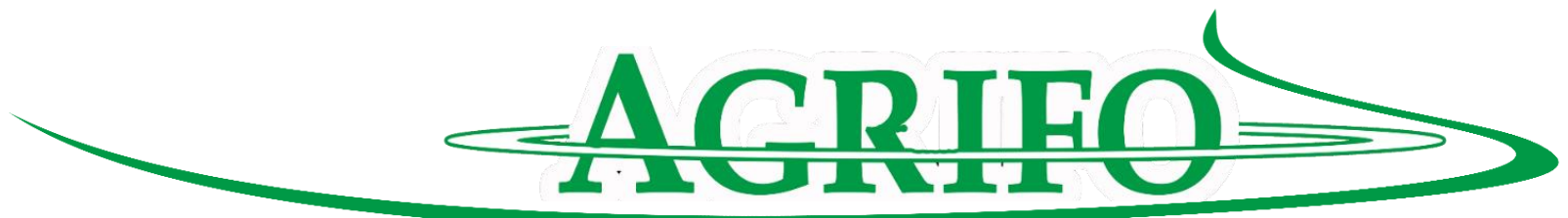

\title{
FAKTOR-FAKTOR YANG MEMPENGARUHI PENGAMBILAN KEPUTUSAN PETANI TERHADAP PENGGUNAAN BENIH PADI DI KECAMATAN NISAM KABUPATEN ACEH UTARA
}

\author{
Hayatul Rahmi ${ }^{1}$, Fadli ${ }^{2}$ \\ email: fadli@unimal.ac.id
}

\begin{abstract}
ABSTRAK
Pengambilan keputusan petani terhadap penggunaan benih padi merupakan salah satu faktor penentu pencapaian hasil optimal dalam suatu usahatani, karena jika salah memilih jenis benih padi maka hasil yang dicapai tidak optimal. Penelitian ini bertujuan untuk menganalisis faktor apa saja yang mempengaruhi keputusan petani terhadap penggunaan benih padi di Kecamatan Nisam Kabupaten Aceh Utara. Metode pengambilan sampel dalam penelitian ini menggunakan Multi Stage Random Sampling dan untuk menentukan besaran sampel digunakan rumus Slovin. Analisis data penelitian menggunakan metode Analisis Regresi Logistik dengan bantuan software SPSS 16. Dari hasil penelitian menunjukkan bahwa ada tiga variabel yang mempengaruhi keputusan petani terhadap penggunaan benih padi yaitu luas lahan, produksi, dan harga benih padi.Sedangkan faktor pendapatan tidak mempengaruhi petani dalam menggunakan benih padi.
\end{abstract}

Kata Kunci: Pengambilan Keputusan Petani, Regresi Logistik

\section{PENDAHULUAN}

Padi (oryza sativa) merupakan tanaman pangan yang dikonsumsi secara umum oleh masyarakat Indonesia sehingga tanaman pangan harus diperhatikan mengingat semakin meningkatnya kebutuhan pangan beras sejalan dengan meningkatnya jumlah penduduk, serta berkembangnya industri pangan.

Kabupaten Aceh Utara merupakan salah satu kabupaten yang masyarakatnya adalah petani padi sawah sehingga diperlukan penanganan khusus untuk padi sawah terutama dalam pemilihan benih. Petani padi sawah yang berada di Kabupaten Aceh Utara khususnya Kecamatan Nisam menggunakan bermacam-macam varietas padi, baik hibrida maupun non hibrida. Namun sebagian besar petani masih menggunakan varietas non hibrida karena varietas non hibrida lebih mudah di dapat, harganya murah, dan selalu tersedia. Sedangkan petani yang menggunakan varietas hibrida, untuk memperolehnya petani harus membeli, harganya lebih mahal, di samping itu varietas hibrida tidak selalu tersedia, sehingga petani dihadapkan kepada suatu pilihan yaitu meneruskan usahataninya dengan tetap menggunakan benih non hibrida atau beralih dari benih non hibrida dan kemudian menggunakan benih hibrida.

\footnotetext{
${ }^{1}$ Mahasiswa Program Studi Agribisnis Universitas Malikussaleh

${ }^{2}$ Staff Pengajar Program Studi Agribisnis Universitas Malikussaleh
} 
Produksi padi di Kecamatan Nisam masih rendah. Salah satu faktor rendahnya produksi adalah penggunaan benih yang tidak bermutu. Petani yang menggunakan benih non hibrida, ratarata produktivitas padinya 5 ton/ha. Sementara petani yang menggunakan benih hibrida, rata-rata produktivitasnya 6 ton/ha. Dapat disimpulkan bahwa semakin tinggi mutu benih yang digunakan, akan semakin besar produksi yang dihasilkan.

Petani sebagai individu pembuat keputusan selalu dipengaruhi oleh ketersediaan sumberdaya rumah tangganya dan juga oleh hubungan sosialnya, yaitu keputusan suatu masyarakat akan mempengaruhi keputusan individu. Di samping itu, perilaku budidaya juga saling berhubungan dengan perilaku sosial, budaya, ekonomi, dan perilaku dari kehidupan masyarakat pedesaan. Bentuk interaksi antar faktor-faktor tersebut pada akhirnya merupakan faktor penentu dalam pembuatan keputusan oleh petani, termasuk dalam keputusan memilih benih yang akan digunakan (Suek, 1994; Gilbert dan Norman, 1980).

Terkait dengan alternatif pilihan benih yang dihadapi petani, menarik untuk ditelaah faktor-faktor apa saja yang mempengaruhi keputusan petani menggunakan benih padi.

Penelitian ini bertujuan untuk menganalisis faktor - faktor yang mempengaruhi keputusan petani terhadap penggunaan benih padi di Kecamatan Nisam Kabupaten Aceh Utara.

\section{METODE PENELITIAN}

Penelitian ini dilakukan di Kecamatan Nisam Kabupaten Aceh Utara yang meliputi tiga desa yaitu Desa Meunasah Krueng, Desa Keutapang, dan Desa Meunasah Meucat. Ruang lingkup penelitian ini hanya dibatasi pada petani yang menggunakan varietas padi hibrida dan non hibrida. Objek Penelitian ini yaitu petani yang melakukan usahatani padi sawah yang menggunakan varietas padi hibrida dan non hibrida.

Populasi dalam penelitian adalah seluruh petani padi sawah yang ada di Desa Meunasah Krueng, Keutapang, dan Meunasah Meucat Kecamatan Nisam Kabupaten Aceh Utara. Penelitian ini dilakukan dengan metode Survei. Jumlah populasi dalam penelitian ini adalah $441 \mathrm{KK}$ petani padi sawah. Untuk menentukan jumlah sampel yaitu dengan menggunakan rumus Slovin (Sevilla et. al., 1960:182), sebagai berikut:

$$
n=\frac{\mathrm{N}}{1+\mathrm{N}(\mathrm{e})^{2}}
$$

Keterangan:

$n$ : Jumlah sampel

$\mathrm{N}$ : Jumlah populasi

e : Batas toleransi kesalahan (error tolerance, $10 \%$ )

Berdasarkan rumus tersebut maka diperoleh jumlah sampel sebanyak 81 orang. Untuk menentukan sampel maka digunakan metode Sampel Bertingkat (Multi Stage random Sampling). Jumlah populasi dan sampel di daerah penelitian dapat dilihat pada tabel berikut. 
Tabel 1. Distribusi lokasi, dan Populasi

\begin{tabular}{|c|c|c|c|}
\hline No & Desa & Populasi (Jiwa) & Sampel \\
\hline 1. & Meunasah Krueng & 129 & 24 \\
\hline 2. & Keutapang & 175 & 32 \\
\hline 3. & Meunasah Meucat & 137 & 25 \\
\hline & Jumlah & 441 & 81 \\
\hline
\end{tabular}

Sumber: Balai Penyuluhan Pertanian Kecamatan Nisam (diolah), 2016

Data yang akan dianalisis adalah faktor-faktor yang mempengaruhi keputusan petani terhadap penggunaan benih padi di Kecamatan Nisam Kabupaten Aceh Utara yaitu luas lahan, produksi, pendapatan usahatani padi, dan harga benih padi (independen). Adapun untuk menganalisis faktorfaktor yang mempengaruhi keputusan petani terhadap penggunaan benih padi (dependen) menggunakan model analisis Logistik (logit). Fungsi tersebut dirumuskan sebagai berikut:

$$
\begin{gathered}
Y=\ln \left(\frac{p i}{1-p i}\right)=\beta_{0}+\beta_{1} X_{1}+\beta_{2} X_{2}+\beta_{3} X_{3}+ \\
\beta_{4} X_{4}+e
\end{gathered}
$$

Keterangan:

$\mathrm{Y}=$ Hibrida atau Non Hibrida

$\beta_{0}-\beta_{4}=$ Intersep

$\mathrm{X}_{1}=$ Luas lahan usahatani (ha)

$\mathrm{X}_{2} \quad=$ Produksi $(\mathrm{Kg})$

$\mathrm{X}_{3}=$ Pendapatan usahatani padi $(\mathrm{Rp})$

$\mathrm{X}_{4}=$ Harga benih $(\mathrm{Rp})$

$\mathrm{E} \quad=$ Error term

Analisis Regresi logistik biner (binomial) digunakan untuk melihat pengaruh sejumlah variabel bebas (X1, $\mathrm{X} 2, \mathrm{X} 3, \mathrm{X} 4)$ terhadap variabel $(\mathrm{Y})$ yang berupa variabel terikat/respon biner yang hanya mempunyai dua nilai. Model logit adalah suatu cara untuk mengkuantitatifkan hubungan dua pilihan (hibrida atau non hibrida), yaitu kategori hibrida $(\mathrm{Y}=1)$ dan non hibrida $(\mathrm{Y}=0)$.
Langkah-langkah dalam pengujian regresi logistik adalah sebagai berikut:

a. Menilai Keseluruhan model (overall model fit/uji G)

Uji $G$ atau pengujian secara keseluruhan/Uji Signifikan Model (Overall Test). Uji signifikansi untuk mengetahui pengaruh variabel bebas terhadap variabel tidak bebas (terikat) di dalam model, maka diuji dengan Uji Likelihood. Adapun kriteria sebagai berikut:

- Jika nilai signifikan dari G<0.1 maka variabel independent secara simultan berpengaruh signifikan terhadap variabel dependent.

- Jika nilai signifikan dari G > 0,1 maka variabel independent secara simultan tidak berpengaruh signifikan terhadap variabel dependent.

b. Menilai kelayakan Model Regresi

1. Uji Hosmer and Lemeshow's Goodness of Fit Test

Kelayakan model regresi dinilai dengan menggunakan Hosmer and Lemeshow's Goodness of Fit Test. Dengan kriteria sebagai berikut:

- Jika nilai statistik Hosmer and Lemeshow's Goodness of Fit Test sama dengan atau kurang 
dari 0,1 maka berarti ada perbedaan signifikan antara model dengan nilai observasinya sehingga Goodness fit model tidak dapat memprediksi nilai observasinya.

- Jika nilai statistik Hosmer and Lemeshow's Goodness of Fit Test lebih besar dari 0,1 maka berarti model mampu memprediksi nilai observasinya atau dapat dikatakan model dapat diterima karena cocok dengan data observasinya.

2. Koefisien Determinan

(Nagelkerke R Square)

Nagelkerke R Square merupakan pengujian yang dilakukan untuk mengetahui seberapa besar variabel independen mampu menjelaskan dan mempengaruhi variabel dependen. Nilai Nagelkerke $R$ Square bervariasi antara 1 (satu) sampai dengan 0 (nol). Jika nilai semakin mendekati 1 maka model dianggap semakin goodness of fit, sementara jika semakin mendekati 0 maka model dianggap tidak goodness of fit (Ghozali, 2011).

\section{Uji Multikolinearitas}

Tingkat korelasi yang cukup tinggi antar dua variabel bebas yakni $\mathrm{r}>$ 0,8 . Jika hal tersebut terpenuhi maka diindikasikan terjadi masalah multikolinearitas dalam persamaan tersebut. Multikolinearitas ini terbagi menjadi dua, yaitu multikolinearitas sempurna apabila $\mathrm{r}=1$ dan multikolinearitas tidak sempurna apabila $\mathrm{r}<1$.

\section{c. Uji Wald}

Pada umumnya, uji ini dilakukan setelah uji signifikan model memutuskan bahwa minimal ada satu variabel bebas yang memiliki pengaruh signifikan terhadap variabel terikat. Tujuannya adalah untuk mencari tahu variabel manakah variabel bebas yang signifikan mempengaruhi variabel terikat tersebut. Pengujian keberartian parameter ( koefisien $\beta$ ) secara parsial dapat dilakukan melalui Uji Wald dengan kriteria sebagai berikut:

- Jika nilai signifikan dari $\mathrm{W}<0,1$ maka variabel independen secara parsial berpengaruh signifikan terhadap variabel dependent.

- Jika nilai signifikan dari W > 0,1 maka variabel independent secara parsial tidak berpengaruh signifikan terhadap variabel dependent.

\section{HASIL DAN PEMBAHASAN}

Berdasarkan data yang diperoleh di Kecamatan Nisam petani menggunakan dua benih padi yaitu benih hibrida dan benih non hibrida (dari hasil panen sebelumnya). Benih non hibrida yang petani gunakan adalah gabah yang sisihkan dari sebagian hasil panen sebelumnya, sedangkan benih hibrida yaitu benih ciherang yang dibeli oleh petani $(5 \mathrm{~kg})$.

Hasil penelitian menunjukkan bahwa petani yang menggunakan benih hibrida sebanyak 38,27\%, sedangkan petani yang menggunakan benih non hibrida sebanyak $61,73 \%$. Dapat disimpulkan bahwa petani yang menggunakan benih non hibrida lebih 
banyak jika dibandingkan dengan petani yang menggunakan benih hibrida.

\section{Faktor-Faktor Yang Mempengaruhi Keputusan Petani Terhadap \\ Metode Regresi Logistik}

Analisis regresi logistik biner (binominal) digunakan untuk meihat pengaruh sejumlah variabel bebas (X1, $\mathrm{X} 2, \mathrm{X} 3, \mathrm{X} 4)$ terhadap variabel terikat (Y) yang berupa variabel biner dan hanya mempunyai dua nilai. Penelitian ini, analisis faktor-faktor yang mempengaruhi keputusan petani terhadap penggunaan benih padi di Kecamatan Nisam Kabupaten Aceh Utara dilakukan dengan menggunakan model regresi binary logistic. Dalam menentukan peluang terpilihnya salah satu kategori dari penggunaan benih padi tersebut harus menjadi kontrol. Pada permasalahan ini, petani menggunakan benih padi non hibrida yang kurang menguntungkan namun petani tetap mempertahankan penggunaan benih tersebut dan tidak mau untuk merubahnya. Dalam hal ini maka keputusan penggunaan benih padi non hibrida diberikan nilai 0 dan keputusan penggunaan benih hibrida diberikan nilai 1. Jumlah data yang digunakan dalam penelitian sebanyak 81 orang.

\section{Analisis Overall Test/Uji G (Chisquare)}

Uji G (Chisquare) dilakukan untuk menguji tingkat signifikan suatu model dalam penelitian. Hasil analisis Uji G dapat dilihat pada tabel berikut:

Tabel 2. Omnibus Tests of Model Coefficients

\begin{tabular}{lllll}
\hline \multirow{2}{*}{ Step 1 } & Chi-square & df & Sig. \\
\cline { 2 - 5 } & Step & 93.070 & 2 & .000 \\
\cline { 2 - 5 } & Block & 93.070 & 2 & .000 \\
\cline { 2 - 5 } & Model & 93.070 & 2 & .000 \\
\hline
\end{tabular}

Uji $\mathrm{G}$ bagi model koefisien menunjukkan bahwa uji statistic $\mathrm{x}^{2}$ adalah untuk menguji $\mathrm{H}_{\mathrm{o}}$, dimana semua koefisien ekspektasi sama dengan nol adalah $x^{2}=93.070$ dengan derajat kebebasan 2 dan nilai sig $=0.000$. Hal ini menunjukkan bahwa regresi logistik sangat signifikan. Dapat disimpulkan bahwa variabel independent secara simultan berpengaruh signifikan terhadap variabel dependent.

Tabel 3. Hosmer and Lemeshow Test

\section{Goodness of Fit}

a) Hosmer Lemeshow

Model estimasi statistik Hosmer dan Lemeshow menyediakan informasi kaliberasi model. Hasil analisis Hosmer Lemeshow dapat dilihat pada tabel berikut.

\begin{tabular}{llll}
\hline Step & Chi-square & df & Sig. \\
\hline 1 & 5.759 & 8 & .674 \\
\hline
\end{tabular}


Tahap signifikan observasi bagi nilai chi square $\left(x^{2}\right)$ yang diperoleh adalah 5.759 (Ujian Hosmer and Lemeshow) dan nilai sig $=0.674>$ alpha (0.1). Hal ini berarti model mampu memprediksi nilai observasinya atau dapat dikatakan model dapat diterima karena cocok dengan data observasinya.

b) Uji Nagelkerke R Square

Untuk mengukur keeratan hubungan antara variabel dependen dan independen juga diestimasi dengan Cox and Snell $R$ Square and Nagelkerke R Square. Nagelkerke's adalah modifikasi lanjutan bagi koefisien Cox and Snell's untuk memastikan bahwa range nilainya antara 1 dan 0 . Biasanya nilai Nagelkerke's lebih besar dari pada nilai Cox and Snell's. Hasil analisis Nagelkerke's dapat dilihat pada tabel berikut:

Tabel 4. Nagelkerke R Square

\begin{tabular}{llll}
\hline & -2 Log likelihood & Cox Step \& Snell R Square & Nagelkerke R Square \\
\hline 1 & $14.722^{\mathrm{a}}$ & .683 & .928 \\
\hline
\end{tabular}

a. Estimation terminated at iteration number 8 because parameter estimates changed by less than .001 .

Dari tabel di atas dapat dilihat bahwa Nagelkerke R Square memberi nilai 0.928. Nilai tersebut menunjukkan kekuatan model yang digunakan dalam penelitian. Dari nilai di atas dapat diartikan bahwa variabel independen mampu menjelaskan variabel dependen sebesar $92,8 \%$, sedangkan sisanya $7,2 \%$ dijelaskan oleh variabel lain diluar model.

\section{c) Uji Multikolinearitas}

Matrik korelasi digunakan untuk melihat apakah terjadi multikolinearitas antar variabel-variabel yang digunakan dalam model penelitian. Hasil analisis Uji Multikolinearitas dapat dilihat pada Tabel 10 berikut:

Tabel 10. Correlation Matrix

\begin{tabular}{lllllll}
\hline & & Constant & $\mathrm{X} 1$ & $\mathrm{X} 2$ & $\mathrm{X} 3$ & $\mathrm{X} 4$ \\
\hline Step 1 & Constant & 1.000 & -.798 & .830 & -.816 & -.941 \\
\cline { 2 - 7 } $\mathrm{X} 1$ & -.798 & 1.000 & -.755 & .703 & .775 \\
\cline { 2 - 7 } $\mathrm{X} 2$ & .830 & -.755 & 1.000 & -.997 & -.750 \\
\cline { 2 - 6 } $\mathrm{X} 3$ & -.816 & .703 & -.997 & 1.000 & .727 \\
\cline { 2 - 6 } & $\mathrm{X} 4$ & -.941 & .775 & -.750 & .727 & 1.000 \\
\hline
\end{tabular}

Tabel 5, terlihat bahwa variabelvariabel dalam model penelitian mengalami multikolinearitas karena nilai korelasi antar variabel bebas melebihi 0,80. Variabel yang mengalami multikolinearitas yaitu X2 (produksi) 
dengan X3 (pendapatan). Untuk mengatasi terjadinya multikolinearitas maka X3 (pendapatan) dikeluarkan.
Hasil analisis setelah X3 (pendapatan) dikeluarkan dapat dilihat pada Tabel 6.

Tabel 6. Correlation Matrix

\begin{tabular}{llllll}
\hline & & Constant & $\mathrm{X} 1$ & $\mathrm{X} 2$ & $\mathrm{X} 4$ \\
\hline Step 1 & Constant & 1.000 & -.760 & .556 & -.903 \\
\cline { 2 - 6 } & $\mathrm{X} 1$ & -.760 & 1.000 & -.933 & .697 \\
\cline { 2 - 6 } & $\mathrm{X} 2$ & .556 & -.933 & 1.000 & -.615 \\
\cline { 2 - 6 } & $\mathrm{X} 4$ & -.903 & .697 & -.615 & 1.000 \\
\hline
\end{tabular}

Dari tabel di atas dapat dilihat bahwa X1 dengan X2 mengalami multikolinearitas karena nilai korelasi antar variabel bebas melebihi 0,80 .
Untuk mengatasi terjadinya multikolinearitas maka X2 dikeluarkan. Setelah X2 dikeluarkan hasil analisis sebagai berikut.

Tabel 7. Correlation Matrix

\begin{tabular}{lllll}
\hline \multirow{2}{*}{ Step 1} & Constant & $\mathrm{X} 1$ & $\mathrm{X} 4$ \\
\cline { 2 - 5 } & Constant & 1.000 & -.774 & -.853 \\
\cline { 2 - 5 } & $\mathrm{X} 1$ & -.774 & 1.000 & .381 \\
\cline { 2 - 5 } & $\mathrm{X} 4$ & -.853 & .381 & 1.000 \\
\hline
\end{tabular}

Tabel 7, terlihat bahwa tidak terjadinya multikolinearitas karena nilai korelasi antar variabel bebas tidak melebihi 0,80

\section{Analisis Classification Table}

Untuk menguji validitas dan aksesibilitas dalam model ini digunakan tabel klasifikasi (Classification Table) untuk mengekspektasi apakah benar atau tidak suatu model dalam penelitian. Model yang telah dibuat akan sangat bergantung kepada estimasi probabilitas untuk keputusan menggunakan benih padi. Keputusan yang diperoleh dalam tabel klasifikasi adalah tingkat sensitivitas model. Tabel klasifikasi pada model penelitian ini dapat dilihat pada Tabel 8 berikut:

Tabel 8. Tabel Klasifikasi

\begin{tabular}{|c|c|c|c|c|c|}
\hline & & & \multicolumn{3}{|c|}{ Predicted } \\
\hline & \multirow{2}{*}{\multicolumn{2}{|c|}{ Observed }} & \multicolumn{2}{|c|}{ Keputusan } & \multirow{2}{*}{ Percentage Correct } \\
\hline & & & Non & $\mathrm{Hib}$ & \\
\hline \multirow[t]{3}{*}{ Step 1} & \multirow[t]{2}{*}{ Keputusan } & Non & 49 & 1 & 98.0 \\
\hline & & HIB & 0 & 31 & 100.0 \\
\hline & Overall Per & & & & 98.8 \\
\hline
\end{tabular}

a. The cut value is .500 
Dari tabel di atas dapat dilihat persentase kasus petani yang menggunakan benih non hibrida yang dapat diestimasi oleh model adalah sebesar 98\%, sedangkan untuk persentase petani yang menggunakan benih hibrida seperti yang diestimasi oleh model adalah sebesar $100 \%$. Tingkat kesalahan dari petani yang menggunakan benih non hibrida oleh model $2 \%$, dan ini bermakna bahwa $2 \%$ dari jumlah petani yang diestimasi oleh model yaitu menggunakan benih non hibrida tetapi sebenarnya menggunakan benih hibrida. Secara keseluruhan model regresi logistik dalam penelitian ini dapat mengestimasi $98.8 \%$ kasus bagi kedua jenis benih padi yang digunakan oleh petani yang ada di Kecamatan Nisam yang dapat dibuktikan dengan koefisien estimasi yang tinggi.

\section{Analisis Metode Logit partial Test/Uji Wald}

Uji ini dilakukan untuk melihat besarnya pengaruh variabel bebas yang memiliki pengaruh signifikan terhadap variabel terikat. Hasil analisis Uji Wald atau uji parsial dapat dilihat pada Tabel 9.

Tabel 9. Uji Wald

\begin{tabular}{llllllll}
\hline & & B & S.E. & Wald & df & Sig. & $\operatorname{Exp}(\mathrm{B})$ \\
\hline \multirow{3}{*}{ Step $1^{\mathrm{a}}$} & $\mathrm{X} 1$ & 5.650 & 4.078 & 1.919 & 1 & .166 & 284.303 \\
\cline { 2 - 8 } & $\mathrm{X} 4$ & .001 & .000 & 14.728 & 1 & .000 & 1.001 \\
\cline { 2 - 8 } & Constant & -11.978 & 3.823 & 9.816 & 1 & .002 & .000 \\
\hline
\end{tabular}

a. Variable(s) entered on step 1: X1, X4.

Dari Tabel 13 di atas, dapat dilihat bahwa variabel bebas yang berpengaruh secara signifikan terhadap keputusan petani menggunakan benih padi adalah variabel harga benih (X4) karena nilai variabel tersebut $<\mathrm{a}(0.1)$. Sedangkan variabel variabel luas lahan (X1) tidak mempengaruhi keputusan petani menggunakan benih padi karena nilai sig $>a(0,1)$.

Persamaan model sebagai berikut:

$\mathrm{Y}=\ln \left(\frac{\mathrm{pi}}{1-\mathrm{pi}}\right)=11.978+5.650 \mathrm{X} 1+$ $0.001 \mathrm{X} 4$

Hasil analisis menunjukkan bahwa nilai koefisien estimasi dari variabel luas lahan (X1) berhubungan positif dengan keputusan petani menggunakan benih padi. Hal ini berarti bahwa petani yang memiliki lahan yang luas akan menggunakan benih hibrida. Nilai odd ratio pada variabel luas lahan adalah 0.166 yang berati bahwa setiap adanya peningkatan luas lahan 1 hektar maka peluang petani untuk menggunakan benih hibrida sebesar 284.303 kali dengan asumsi bahwa semua faktor lain dianggap tetap.

Luas lahan di daerah pedesaan umumnya tergolong sedang dan sempit, namun ada beberapa petani yang memiliki luas lahan yang luas. Luas tidaknya lahan yang dimiliki oleh petani secara teoritis akan mempengaruhi petani dalam memutuskan jenis benih yang akan digunakan. Di lokasi penelitian, luas lahan terbesar yaitu seluas 1.5 ha, sedangkan luas lahan terkecil yaitu 0.16 ha dan rata-rata luas lahan di daerah penelitian adalah 0,5 ha 
atau setara dengan 12,5 rante. Petani yang memiliki luas lahan yang luas tentu lebih banyak akan kebutuhan benih padi dari pada petani yang memiliki luas lahan sempit.

Sedangkan variabel harga benih nilai koefisien estimasi dari variabel harga benih memiliki nilai koefisien positif dengan keputusan petani menggunakan benih hibrida. Hal ini berarti bahwa semakin tinggi harga benih maka petani akan menggunakan non hibrida. Nilai ood ratio pada variabel harga benih sebesar 0.000 yang berarti bahwa setiap adanya peningkatan harga benih sebesar Rp 1 maka peluang petani menggunakan benih non hibrida akan meningkat sebesar 1 kali dengan asumsi semua faktor lain dianggap tetap.

Berdasarkan penelitian, harga benih non hibrida adalah $5.000 / \mathrm{kg}$, sedangkan harga benih hibrida mencapai $12.000 / \mathrm{kg}$ sampai $16.000 / \mathrm{kg}$. Semakin mahal harga benih hibrida yang dijual maka petani akan menggunakan benih non hibrida tetapi petani memiliki peluang untuk menggunakan benih hibrida karena petani bisa membayar benih hibrida setelah panen. Harga benih bertanda positif dan signifikan pada taraf kepercayaan $90 \%(a=0.1)$.

\section{KESIMPULAN}

Faktor yang mempengaruhi keputusan petani menggunakan benih padi di Kecamatan Nisam Kabupaten Aceh Utara dipengaruhi oleh faktor harga benih padi. Sedangkan faktor luas lahan, produksi, dan pendapatan tidak mempengaruhi keputusan petani terhadap penggunaan benih padi.

\section{SARAN}

1. Bagi Petani, diharapkan dalam mengambil keputusan menggunakan jenis benih yang lebih menguntungkan yang akan digunakan untuk penanaman.

2. Bagi Pemerintah, diharapkan bisa memberikan pelatihan dan pengetahuan kepada petani padi sawah tentang penggunaan benih padi yang lebih menguntungkan sehingga petani tidak salah menggunakan benih padi yang akan ditanam.

\section{DAFTAR PUSTAKA}

Ghozali, I. 2011. "Aplikasi Analisis Multivariatedengan Program SPSS". Badan Penerbit Universitas Diponogero. Semarang.

Sevilla, C. G.et. al. 1960. Research Methods. Quezon City: Rex Printing Company. 